\title{
Perancangan Sistem Informasi Persediaan Produk Kaos Berbasis Metode Period Order Quantity (Study Kasus: PD.Teguh Kaos Polos)
}

\author{
Bramantiyo Eko Putro ${ }^{1}$, Ujang Arif Taufik ${ }^{2}$ \\ ${ }^{1,2}$ Teknik Industri Universitas Suryakancana \\ Jl. Pasir Gede Raya Cianjur \\ ${ }^{1}$ Email: bramantiyo@unsur.ac.id
}

Dikirimkan: 07, 2018 . Diterima: 09, 2018. Dipublikasikan: 10, 2018.

\begin{abstract}
Economic growth causes goods and services produced to increase and competition in the process of meeting the needs of consumers. PD.TEGUH KAOS POLOS is a trading company engaged in the field of clothing. The existing problem is the stockpile of goods that cause large inventory and not necessarily when the time of purchase of raw materials and the process of recording transactions, whether the purchase transactions and sales transactions are still using the manual with a note and ledger. The purpose of this study to determine the economic order and frequency of optimal ordering time by using Period Order Quantity method with the help of management information system design to help find out the information system needs regarding the amount of stock available. POQ calculation results obtained that the optimal order amount of 1803 units / pcs with the frequency of ordering 11 times and the distance between reservations for 29 days. There was a decrease in stock buildup around 7626 units / pcs. POQ decreases message costs and saves Rp.36.171.103 which can save company costs. Functionally a company needs a computerized information system and non-functional companies need a computer device CPU with the help of XAMPP software to run the database. With inventory information system using POQ saves working time to be more effective and efficient.
\end{abstract}

Keywords - Forecasting; Period Order Quantity; Management Information System; Information System Design.

\begin{abstract}
Abstrak - Pertumbuhan ekonomi menyebabkan barang dan jasa yang diproduksi mengalami peningkatan dan persaingan dalam proses pemenuhan kebutuhan pada konsumen. PD.TEGUH KAOS POLOS merupakan perusahaan dagang yang bergerak di bidang sandang. Permasalahan yang ada yaitu penumpukan stock barang yang menimbulkan inventory besar dan tidak tentunya kapan waktu pembelian bahan baku serta proses pencatatan transaksi, baik itu transaksi pembelian dan transaksi penjualan masih menggunakan cara manual dengan nota dan buku besar. Tujuan penelitian ini untuk mengetahui pesanan yang ekonomis serta frekuensi waktu pemesanan yang optimal dengan menggunakan metode Period Order Quantity dengan bantuan perancangan sistem informasi manajemen untuk membantu mengetahui kebutuhan sistem informasi mengenai jumlah stock yang tersedia. Hasil perhitungan POQ didapat bahwa jumlah pemesanan yang optimal sebesar 1803 unit/pcs dengan frekuensi pemesanan 11 kali dan jarak antar pemesanannya selama 29 hari. Terjadi penurunan penumpukan jumlah stock sekitar 7626 unit/pcs. POQ menurunkan biaya pesan dan simpan sebesar Rp.36.171.103 yang dapat menghemat biaya perusahaan. Secara fungsional perusahaan memerlukan sistem informasi yang terkomputerisasi dan secara non-fungsional perusahaan memerlukan perangkat komputer CPU dengan bantuan software XAMPP untuk menjalankan database. Dengan sistem informasi persediaan menggunakan POQ menghemat waktu kerja menjadi lebih efektif dan efisien.
\end{abstract}

Kata kunci- Peramalan; Period Order Quantity; Sistem Informasi Manajemen; Perancangan Sistem Informasi; 


\section{Pendahuluan}

Proses produksi erat kaitannya dengan sistem inventory (persediaan), yaitu untuk menjamin lancarnya proses produksi. Persediaan adalah bahan-bahan, bagian yang disediakan, dan bahanbahan dalam proses yang terdapat dalam perusahaan untuk proses produksi, serta barangbarang jadi atau produk yang disediakan untuk memenuhi permintaan dari konsumen atau pelanggan setiap waktu [1]. Kegiatan produksi tidak hanya berorientasi pada produk yang dihasilkan, tetapi bagaimana cara menjaga bahan baku agar produksi itu dapat berjalan. Persediaan yang berlebih akan menimbulkan biaya penyimpanan yang besar disamping dampaknya akan menimbulkan biaya tambahan, sedangkan persediaan yang terlalu kecil akan menyebabkan stock kosong yang berpengaruh terhadap kepuasan pelanggan [2].

Oleh karena itu, untuk menghindari stock kosong, perusahaan biasanya mempunyai safety stock sebagai pengaman bila terjadi fluktuasi permintaan. Menurut Rangkuti [1] dalam bukunya menjelaskan bahwa "pengaman persediaan (safety stock) adalah persediaan tambahan yang diadakan untuk melindungi atau menjaga kemungkinan terjadinya kekurangan bahan atau stock out". Selain safety stock, kebutuhan akan memesan kembali atau reorder point sangatlah dibutuhkan. Reorder point atau pemesanan kembali adalah "Suatu titik atau batas dari jumlah persediaan yang ada pada suatu saat dimana pemesanan harus diadakan kembali” [3].

Permasalahan persediaan ini dapat dibantu dengan sistem informasi yang baik [4]. O'brien dan Marakas mengemukakan bahwa sistem informasi adalah berbagai kombinasi dari manusia, perangkat keras, perangkat lunak, jaringan komunikasi, sumber data, kebijakan dan prosedur yang mampu menyimpan, mengumpulkan, mengubah, dan menyebarluaskan informasi dalam suatu organisasi [5].

PD. Teguh Kaos Polos merupakan perusahaan dagang yang bergerak di bidang sandang. Permasalahan yang ditemui yaitu penumpukan stock barang (stock berlebih) sehingga menimbulkan inventory yang besar. Selain itu karena tidak tentunya kapan pembelian bahan baku sehingga hanya berdasarkan perkiraan saja yang mengakibatkan terjadinya penumpukan stock.

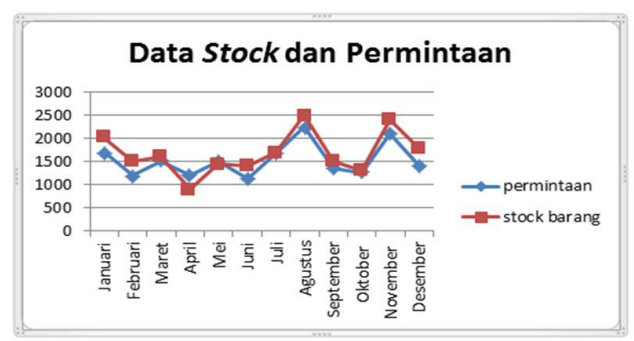

Gambar 1. Permintaan dan stock kaos pada bulan JanuariDesember 2016 (sumber: PD. Teguh Kaos Polos)

Diketahui pada gambar 1 bahwa pada bulan Januari-Maret terdapat stock yang berlebih dibandingkan permintaan, mengakibatkan adanya ongkos simpan. Sedangkan untuk bulan April ada kenaikan permintaan, namun stock di gudang habis. Akibatnya konsumen harus menunggu barang pesanan untuk selanjutnya diproses dan ini dapat mengurangi kepuasaan terhadap konsumen. Pada bulan Mei-Desember terjadi penumpukan stock yang mengakibatkan adanya ongkos ekstra (ongkos simpan).

Permasalahan lain dari proses pencatatan transaksi, baik itu transaksi pembelian dan transaksi penjualan masih menggunakan cara manual dengan nota dan buku besar (Bapak Teguh, 20 September 2017). Proses manual mengakibatkan terjadinya kekeliruan dan kesalahan dalam pencatatan. Hal tersebut menyulitkan pemilik dalam menentukan stock produk yang ada. Selain itu mengenai bagian sistem informasinya masih tergolong minim sehingga PD. Teguh Kaos Polos ini membutuhkan suatu alat bantu hitung untuk menentukan kapan pemesanan yang optimal serta untuk mendata supplier dan keseluruhan bahan baku stock dengan bantuan sistem informasi.

Berdasarkan latar belakang diatas maka rumusan masalah pada penelitian ini adalah:

1. Apakah dengan metode Periodic Order Quantity ini dapat mengurangi persediaan berlebih serta dapat menentukan kuantitas pembelian yang optimal?

2. Bagaimana kebutuhan sistem informasi di PD. Teguh Kaos Polos?

3. Apakah dengan sistem informasi manajemen persediaan dapat menginformasikan jumlah persediaan yang tersedia?

\section{Metodologi Penelitian}

1. Studi Pustaka

Studi pustaka dilakukan dengan tujuan untuk mengetahui metode apa yang akan digunakan oleh peneliti dalam menyelesaikan permasalahan yang ada. Pada tahap ini merupakan bahasan pengumpulan pengetahuan yang ditinjau dari segi 


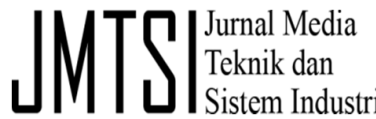

peramalan, persediaan, sistem informasi manajemen dan lain-lain yang didapat dari sumber-sumber seperti buku, jurnal, internet dan sumber lainnya.

\section{Pengumpulan Data}

Informasi atau data dapat dibedakan berdasarkan sumbernya, antara lain data dari tangan pertama (data primer), dan data dari tangan kedua, ketiga, dan seterusnya (data sekunder) [6]. Dalam mencari data ini, peneliti mengambil dua klasifikasi pengumpulan data, yaitu:

\section{A. Data Primer}

Data primer adalah data yang diperoleh secara langsung dari sumbernya [6]. Untuk mengumpulkan data primer peneliti menggunakan dua metode, yaitu:

a. Studi Lapangan (Observasi)

Studi lapangan (observasi) adalah melakukan pengamatan dan pencatatan secara sistematis terhadap gejala yang diselidiki, tanpa mengajukan pertanyaan-pertanyaan. [6]. Pada tahap ini peneliti melakukan studi lapangan (observasi) pada perusahaan dagang PD. Teguh Kaos Polos yang belum memiliki perencanaan persediaan yang baik dalam menentukan langkah pembelian yang optimal serta belum memiliki sistem informasi manajemen yang terkomputerisasi.

\section{b. Wawancara}

Wawancara (interview) merupakan cara pengumpulan data dengan jalan tanya-jawab sepihak yang dikerjakan secara sistemik dan berdasarkan tujuan penelitian. [6]. Pada tahap ini peneliti melakukan wawancara dengan pemilik PD. Teguh Kaos Polos untuk memperoleh keterangan lebih banyak mengenai objek penelitian untuk selanjutnya data ini akan diolah oleh peneliti.

\section{B. Data Sekunder}

Data sekunder adalah data yang bukan diusahakan sendiri pengumpulannya oleh peneliti. [6]. Data sekunder yang diambil oleh peneliti yaitu berupa sejarah perusahaan, struktur organisasi perusahaan, laporan penjualan, dan data lain-lain yang dibutuhkan untuk penelitian.

\section{Jenis Penelitian}

Pada tahap ini jenis penelitian yang digunakan adalah penelitian dengan metode campuran (mix methods). Menurut Creswell [7] penelitian campuran (mix methods) adalah metode penelitian yang mengkolaborasikan antara penelitian kualitatif dengan penelitian kuantitatif.
4. Perhitungan Period Order Quantity (POQ)

Metode POQ pada dasarnya adalah memesan barang dengan interval pesan $(T)$ yang tetap dengan jumlah ukuran lot pemesanan sama dengan kebutuhan barang dalam selama periode pemesanan yang dicakup [8]. Cara penentuan $T$ tersebut didasarkan atas formula Wilson dengan cara sebagai berikut:

a. Hitung Economic Order Quantity (EOQ).

$\mathrm{EOQ}=\sqrt{\frac{2 A D}{h}}$

Dimana :

$\mathrm{A}=\quad$ Biaya pemesanan

$\mathrm{D}=$ Jumlah Pemesanan dalam

periode tertentu

$\mathrm{h}=\quad$ Biaya simpan

b. Hitung jumlah (frekuensi) pemesanan $f$, yaitu dengan membagi permintaan per-tahun (D) dengan EOQ. Bulatkan ke atas bila hasil pembagian (nilai $f$ ) bukan bilangan bulat.

$f=\frac{D}{E O Q}$

dimana :

$\mathrm{D}=\quad$ Permintaan barang per-tahun

c. Hitung POQ dengan membagi jumlah periode per-tahun $(P)$ dengan $f$. Hasil pembagian ini kemudian dibulatkan ke atas.

$$
\mathrm{T}=\frac{N}{f}
$$

5. Perancangan Sistem Informasi

Pada tahap ini dilakukan perancangan sistem informasi yang ada dengan sistem informasi usulan yang akan dilakukan oleh peneliti di PD. Teguh Kaos Polos. Perancangan sistem informasi yang dilakukan adalah pembuatan flow map yaitu bagan-bagan yang mempunyai arus yang menggambarkan langkah-langkah penyelesaian suatu masalah. [9], diagram alir data (data flow diagram) menurut [10] suatu network yang akan menggambarkan suatu sistem otomatis atau terkomputerisasi, manualisasi atau gabungan dari keduanya yang penggambarannya disusun dalam bentuk kumpulan komponen yang saling berhubungan sesuai dengan aturan mainnya., dan entity relation diagram (ERD) menurut [9] adalah suatu model jaringan yang menggunakan susunan data yang disimpan dalam sistem secara abstrak.

\section{Perancangan Database}

Database atau dalam bahasa Indonesianya basis data adalah kumpulan data yang disusun, diorganisasikan dan disimpan secara sistematik yang saling berhubungan antara satu dengan yang lainnya [11]. Pada tahap ini perancangan yang dilakukan adalah pembuatan / input database 
dengan bantuan bahasa pemrograman PHP (Hypertext Preprocessor) dan MySQL.

\section{Perancangan Interface}

Pada tahap ini dilakukan suatu perancangan bentuk interface program yang akan dibuat. Tujuan dalam bentuk interface ini agar pemakai mengerti dalam pengoperasian program yang telah dibuat. Perancangan ini di meliputi menu, fitur-fitur yang akan disediakan, serta tampilan yang akan dirancang. Pada perancangan ini dibantu dengan MySQL dan XAMPP (program yang menjalankan PHP dan MySQL).

\section{HAsil PENELITIAN}

1. Peramalan

Peramalan (forecasting) merupakan alat bantu perencanaan yang efektif dan efisien digunakan untuk memprediksi atau mengestimasi permintaan di masa yang akan datang [12].

a. Single Moving Average

Metode rata-rata bergerak ini menghitung deret berkala dari data asli dan diubah menjadi deret rata-rata bergerak yang lebih mulus.

\section{b. Single Eksponential Smoothing}

Pada peramalan ini data yang dihitung diberi bobot alpha $(\alpha)$ sesuai pola data aktual. Alpha $(\alpha)$ yang digunakan sebesar $\alpha=0,5$. Karena pola data aktual pada penjualan tidak stabil atau bergejolak dari waktu ke waktu dan tingkat ketepatannya pun dirasa sudah mendekati.

\section{c. Regresi Linier}

Pada peramalan regresi linier ini untuk menentukan nilai peramalan dicari terlebih dahulu nilai a dan b nya dengan memakai rumus-rumus yang telah ditentukan.

Tabel 3 perhitungan Regresi Linier

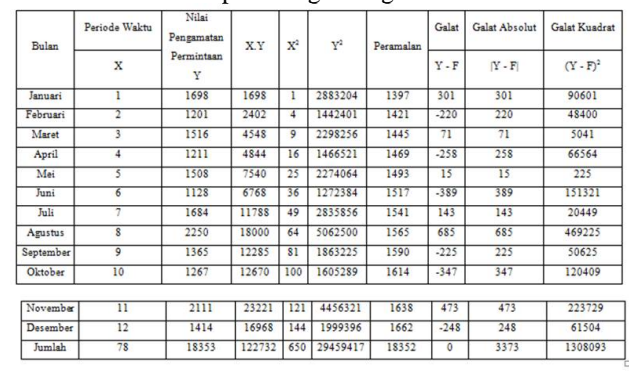

d. Peramalan Konstan

Pada peramalan ini cara untuk menentukan nilai peramalan dilakukan dengan mengambil rata-rata data masa lalu.

Perbandingan hasil peramalan
Tabel 5 Perbandingan peramalan

\begin{tabular}{|c|c|}
\hline Metode Peramalan & Standar Deviasi Error (SDE) \\
\hline Single Moving Average & 450 \\
\hline Single Eksponetial Smoothing & 463 \\
\hline Regresi Linier & 345 \\
\hline Peramalan Constant & 355 \\
\hline
\end{tabular}

Dari hasil perhitungan peramalan, dapat dilihat perbandingan pada tabel IV.6 dengan Single Moving Average, Single Eksponential Smoothing, Regresi Linier dan Peramalan Konstan maka didapat nilai Standar Deviasi Error (SDE) yang terkecil adalah perhitungan peramalan dengan metode Regresi Linier sehingga hasil peramalan ini akan digunakan untuk perhitungan Period Order Quantity (POQ).

Tabel 6 Data permintaan hasil peramalan

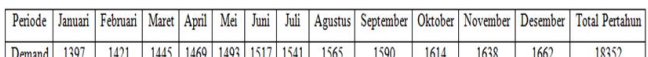

2. Period Order Quantity (POQ)

Diketahui -Ongkos Pesan (A) = Rp.420.175,

-Ongkos simpan (h) =Rp.4.743,

-Harga Kaos = Rp. 40.000,

a. Economic Order Quantity (EOQ).

$$
\begin{aligned}
& \mathrm{EOQ}=\sqrt{\frac{2 A D}{h}} \\
& \mathrm{EOQ}=\sqrt{\frac{2 \times 420175 \times 18352}{4743}} \\
& \mathrm{EOQ}=1803 \mathrm{pcs}
\end{aligned}
$$

Jadi pemesanan yang optimal didapat sebanyak 1803 unit/pcs untuk setiap pemesanan.

b. Frekuensi Pemesanan

$$
\begin{aligned}
f & =\frac{D}{E O Q} \\
f & =\frac{18352}{1803} \\
f & =10,17 \\
f & =11 \text { (dibulatkan ke atas) }
\end{aligned}
$$

Jadi frekuensi pemesanannya dapat dilakukan sebanyak 11 kali dalam setahun.

c. Period Order Quantity

$$
\begin{aligned}
& \mathrm{POQ}=\frac{N}{f} \\
& \mathrm{POQ}=\frac{312}{11} \\
& \mathrm{POQ}=28,36 \\
& \mathrm{POQ}=29 \text { (dibulatkan ke atas) }
\end{aligned}
$$




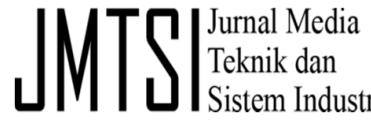

Jadi jarak antar pemesanannya didapat selama 29 hari.

Perbandingan inventory, biaya pesan dan simpan pada perusahaan dengan POQ

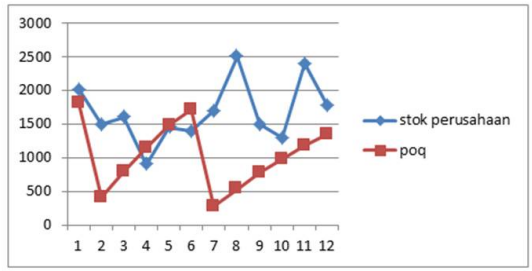

Gambar 2 Grafik perbandingan persediaan perusahaan dengan persediaan hasil perhitungan POQ

3. Perancangan Sistem Informasi

A. Flow Map

Flow map usulan bagi perusahaan.

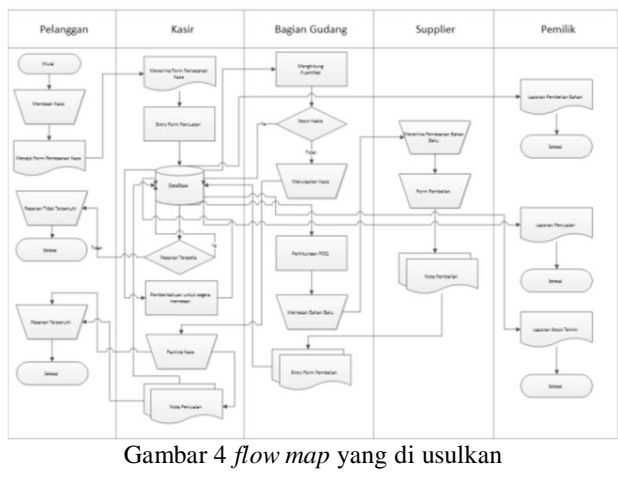

B. Diagram Konteks

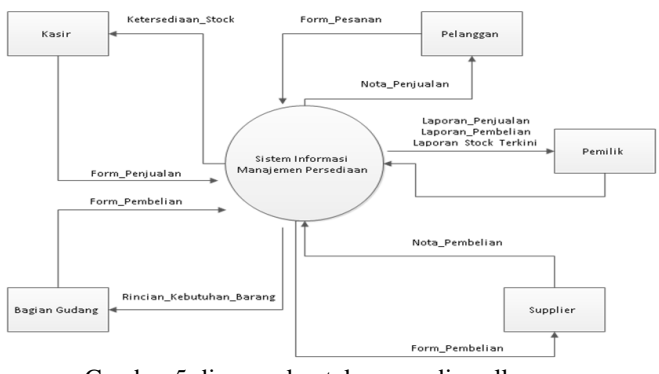

Gambar 5 diagram konteks yang di usulkan

C. Diagram Alir Data

- Diagram Alir Data Level 1

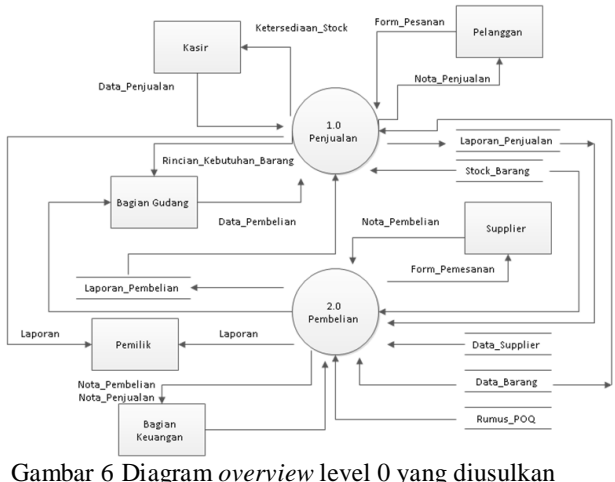

Gambar 6 Diagram overview level 0 yang diusulkan

D. Entity Relation Diagram

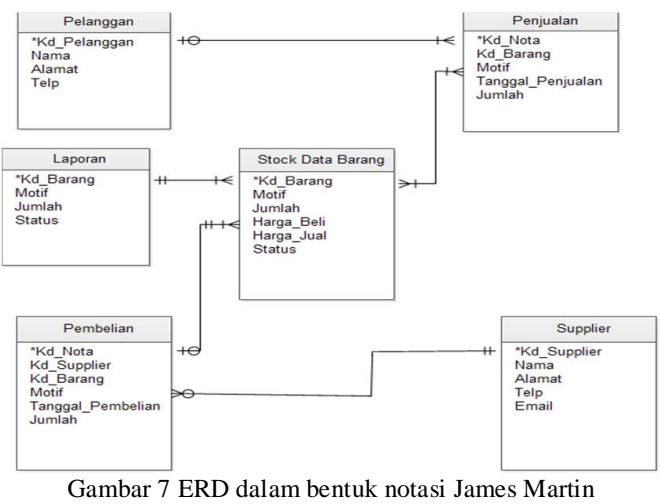

4. Perancangan Database

Tampilan database dengan menggunakan aplikasi XAMPP yang dibuka melalui aplikasi browser Mozilla Firefox dengan memasukan link localhost/phpmyadmin maka akan tampil dalam bentuk offline. Pada gambar 4.14 ini merupakan database yang dibuat berdasarkan ERD yang meliputi database laporan, pelanggan, pembelian, penjualan, stock data barang dan supplier.

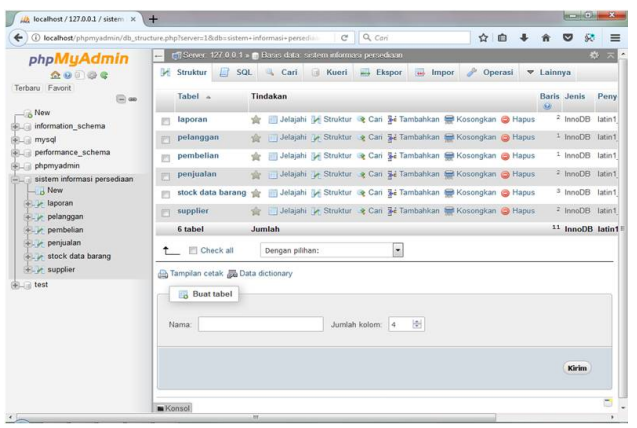

Gambar 8 Tampilan Database Sistem Informasi Persediaan dengan PHPMYADMIN 
5. Perancangan Interface

a. Tampilan Depan

Dalam tampilan depan ini meliputi bagian pembuka anatra lain terdapat menu-menu form penjualan, form pembelian, form stock data barang, form data supplier dan form laporan. Dan apabila ingin masuk ke menu form, tinggal mengklik lihat.

\section{b. Form Penjualan}

Pada form ini terdapat input masukan dari penjualan yang meliputi kode nota, kode barang, motif, jumlah dan tanggal penjualan. Terdapat pula pilihan simpan form untuk menyimpan data penjualan dan pilihan cetak untuk mencetak data penjualan dan memberikannya kepada pelanggan. Dalam form ini pun ada hyperlink untuk langsung masuk ke bagian depan halaman dengan mengklik pilihan beranda.

\section{c. Form Pembelian}

Pada Form ini terdapat beberapa input yang meliputi kode nota, kode supplier, kode barang, motif, jumlah, dan tanggal pembelian. Input-an pada form ini merupakan input-an hitung Period Order Quantity (POQ). Jadi ketika mengklik hitung, maka akan keluar tampilan biaya pesan, biaya simpan, jumlah barang yang akan dipesan, frekuensi pemesanan dan interval tiap pemesanannya. Dalam form ini terdapat juga hyperlink untuk langsung masuk ke bagian depan halaman dengan mengklik pilihan beranda.

\section{d. Form Stock Data Barang}

Pada form terdapat inputan untuk penambahan stock yang meliputi kode barang, motif, jumlah, harga beli, dan harga jual. Form ini dapat memberitahu bagian gudang ketika stock akan segera habis dengan batas stock $\leq 25$. Dalam form ini terdapat juga hyperlink untuk langsung masuk ke bagian depan halaman dengan mengklik pilihan beranda.

\section{e. Form Data Supplier}

Pada form ini terdapat beberapa input diantaranya kode supplier, nama, alamat, telp dan email. Terdapat juga pilihan mengubah atau menghapus data supplier. Dalam form ini terdapat juga hyperlink untuk langsung masuk ke bagian depan halaman dengan mengklik pilihan beranda.

\section{f. Laporan}

Pada bagian ini hanya menampilkan kode barang, motif, jumlah dan status untuk selanjutnya dapat dilihat oleh pemilik atau bagian yang terlibat. Dalam form ini terdapat juga hyperlink untuk langsung masuk ke bagian depan halaman dengan mengklik pilihan beranda.

\section{PEMBAHASAN}

1. Analisis Peramalan

Berdasarkan pola data permintaan, pola data cenderung mengarah kepada linier dan konstan. Sehingga pada peramalan ini menggunakan empat metode peramalan, diantaranya peramalan dengan menggunakan Single Moving Average, Single Eksponential Smoothing, Regresi Linier dan Peramalan Konstan. Dari keempat metode peramalan tersebut, didapat perbandingan standar deviasi error terkecil dengan menggunakan Regresi Linier sebesar 345. Nilai ini menunjukan, bahwa angka kesalahannya lebih kecil dari ketiga metode yang dibandingkan, sehingga peramalan yang digunakan adalah peramalan dengan metode Regresi Linier.

\section{Persediaan Menggunakan Period Order Quantity}

Berdasarkan data perusahaan dan hasil perhitungan dengan mengunakan metode POQ, dapat diperoleh bahwa ada perbandingan penurunan jumlah stock barang yang signifikan setelah dihitung dengan metode POQ. Perhitungan ini menghasilkan pemesanan yang optimal sebanyak 1803 unit dan dapat dilakukan dengan frekuensi pemesanan sebanyak 11 kali jarak antar pemesananya selama 29 hari. Dengan demikian perusahaan akan dapat menentukan kebutuhan bahan baku yang maksimal dengan metode POQ ini.

3. Analisis Optimasi Ongkos Pesan dan Ongkos Simpan

Berdasarkan hasil perhitungan data perusahaan, didapat total ongkos pesan dan ongkos simpan perusahaan sebesar Rp. 99.671.645,. Sedangkan ongkos pesan dan ongkos simpan dengan menggunakan metode POQ didapat sebesar Rp.63.500.542,. Sehingga dengan demikian metode POQ dapat menurunkan stock persediaan dengan mengoptimalkan ongkos pesan dan ongkos simpan.

\section{Analisis Kondisi Perusahaan}

Berdasarkan penelitian yang dilakukan di PD.Teguh Kaos Polos diketahui bahwa perusahaan mempunyai beberapa permasalahan, diantaranya terdapat stock barang yang berlebih yang dapat menimbulkan ongkos simpan yang besar. Selain itu proses pencatatan transaksi, baik itu transaksi pembelian dan transaksi penjualan masih menggunakan cara manual dengan nota dan buku besar yang dapat mengakibatkan kekeliruan 


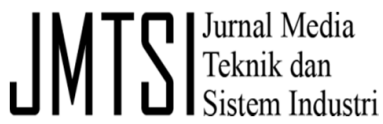

yang pada akhirnya dapat merugikan perusahaan. Permasalahan lain yang ditemui yaitu minimnya sistem informasi yang berakibat kurangnya koordinasi antar bagian yang dapat menyebabkan mis komunikasi sehingga kurang efektif dan efisien.

\subsection{Analisis Kebutuhan}

Analisis ini terbagi kedalam dua bagian, antara lain analisis kebutuhan Fungsional dan analisis kebutuhan Non-Fungsional.

A. Analisis Kebutuhan Fungsional Dalam analisis ini didapat ringkasan mengenai kebutuhan informasi pada perusahaan, diantaranya:

a. Perusahaan membutuhkan sistem informasi yang terintegrasi untuk mempermudah dalam mengolah data penjualan dan data pembelian barang serta untuk mengetahui persediaan yang ada di gudang.

b. Dalam penentuan pembelian bahan baku, perusahaan harus melakukan perhitungan terlebih dahulu agar tidak ada stock yang menumpuk.

c. Proses pencatatan transaksi, baik itu transaksi pembelian dan transaksi penjualan masih menggunakan cara manual dengan nota dan buku besar yang dapat mengakibatkan kekeliruan. Pengelolaan data selama ini belum efisien sehingga pekerjaan belum efektif dengan baik.

B. Analisis Non-Fungsional

Pada analisis ini kebutuhan ini terbagi kedalam dua bagian, antara lain kebutuhan perangkat lunak (software) untuk menjalankan hardware dan perangakat keras (harware) untuk mendukung kinerja software.

a. Kebutuhan Perangkat Lunak (Software) Perangkat lunak yang mendukung sistem ini adalah sebagai berikut:

1. Sistem operasi Windows XP, Windows Vista, Windows 7, dan Windows 8

2. Aplikasi XAMPP

3. Aplikasi Sublime Text 3

4. Browser Mozilla Firefox

b. Kebutuhan Perangkat Keras (Hardware)

1. CPU Processor Intel Core 2 Duo

2. Random Acces Memory (RAM) minimal $512 \mathrm{MB}$

3. Video Graphic Array (VGA) minimal 512 MB

4. Penyimpanan Harddisk

5. CD-ROM
6. Monitor

7. Mouse dan Keyboard

8. Printer

5. Analisis Flow Map Penjualan dan Pembelian Yang Sedang Berjalan

Prosedur pemesanan dilakukan oleh pelanggan dengan mengisi form pemesanan dan memberikannya kepada kasir. Pada saat menerima form pemesanan, kasir tidak bisa secara langsung memenuhi kebutuhan pelanggan. Akan tetapi kasir harus mengecek dulu ke bagian gudang apakah tersedia atau tidak. Hal ini mengakibatkan kurang efisiennya waktu hingga dapat memakan waktu yang lama dalam melayani pelanggan yang dapat mengurangi kepuasan kepada pelanggan.

Selain itu untuk menentukan pembelian stock bagian gudang harus mengecek dan menghitung terlebih dahulu apakah stock masih ada atau sudah habis. Pemilik juga menuturkan bahwa pembelian dilakukan setelah melihat stock kosong yang dilihat secara kasat mata. Sehingga dalam aktivitas ini sangat kurang efektif karena dapat terjadi kekeliruan pembelian barang yang dapat mengakibatkan terjadinya penumpukan barang.

6. Analisis Flow Map Penjualan dan Pembelian Yang Diusulkan

Dari flow map yang diusulkan pada gambar 4.8, dapat dilihat ada perubahan sistem alurnya. Dimana dalam prosedur ini sudah menggunakan basis komputerisasi. Dalam penerimaan pemesanan kasir menerim form pemesanan dan langsung meng-input form pemesanan. Sehingga ketika proses meng-input selesai, maka output yang akan keluar ialah stock tersedia atau tidak. Jika tersedia, maka proses pemesanan dapat terpenuhi dan stock yang tersisa akan terlihat karena sudah terintegrasi dengan bagian gudang.

Dalam sistem ini, proses input dan output data sudah menggunakan database dalam sistem komputer. Sistem ini sudah terintegrasi ke setiap bagian dan dapat diakses oleh setiap bagian atau pemilik dalam meng-input atau hanya sekedar memperoleh atau melihat informasi. Sistem informasi ini pun dapat memudahkan seorang pemilik mengecek setiap penjualan atau pembelian yang terjadi dan dapat juga melihat stock barang yang tersisa.

Sistem proses penjualan dan pembelian yang terkomputerisasi memudahkan dalam proses pembelian bahan baku dengan bantuan peritungan POQ yang dapat mengurangi penumpukan stock yang berlebih. Pembuatan data supplier sebagai 
pemasok bahan juga sudah termasuk dalam sistem, sehingga dapat membantu dalam proses pemenuhan kebutuhan perusahaan. Selain itu, laporan pembelian dan penjualan dapat terlampir serta dapat disimpan ataupun dicetak.

7. Analisis Diagram Konteks

a. Pelanggan

Bagian ini memiliki dua aliran data, yaitu form pemesanan yang dibutuhkan pelanggan dan nota penjualan dari sistem untuk pelanggan karena kebutuhan telah terpenuhi.

b. Kasir

Bagian kasir ini memiliki dua aliran data, dimana setelah menerima pesanan, kasir meng-input form penjualan ke sistem. Setelah itu, sistem membalas dengan menginformasikan ketersediaan stock.

c. Bagian Gudang

Setelah terjadinya proses penjualan, maka stock yang tersedia berkurang. Bagian gudang memiliki dua aliran data, yaitu menerima kebutuhan barang dari sistem apabila barang yang ada sudah hampir habis.

Selanjutnya bagian gudang membeli bahan baku pada supplier dan meng-input nya pada form pembelian yang selanjutnya akan diketahui berapa jumlah yang harus dipesan dalam sekali pesan, frekuensi pemesanannya berapa kali dan jarak antar pemesanannya berapa hari.

d. Supplier

Pada proses ini terjadi juga dua aliran data, yaitu setelah kebutuhan jumlah pesan diketahui, maka sistem memberikan form pembelian pada supplier dan supplier memberikan nota pembelian pada sistem.

e. Pemilik

Pada proses ini sistem memberitahukan laporan pembelian, laporan penjualan, dan laporan stock terkini. Pemilik dapat mengontrol dengan memantau sistem informasi persediaan.

Diagram konteks ini menjelaskan seluruh kegiatan dan alur proses data yang terjadi, sehingga memudahkan seorang pemilik dalam melakukan pengawasan pada perusahaannya.

8. Diagram Alir Data

Diagram alir data merupakan pemecahan dari diagram konteks. Pada diagram alir data ini terbagi atas tiga level, yaitu level 0 , level 1, dan level 2.

a. Diagram alir data level 0

Menjelaskan keseluruhan bagian sistem infromasi persediaan yang meliputi proses penjualan dan proses pembelian. b. Diagram alir data level 1 menjelaskan pemecahan dari proses penjualan yang Memiliki tiga proses, yaitu permintaan pemesanan, pengecekan barang, dan laporan penjualan.

c. Diagram alir data level 2

Menjelaskan pemecahan dari proses penjualan yang memiliki tiga proses, yaitu kebutuhan barang, rincian kebutuhan dan pembelian barang.

Jadi proses digram alir data ini menjelaskan secara rinci alur proses dari sistem informasi persediaan yang diusulkan.

\section{Analisis Entity Relation Diagram (ERD)}

Hasil perancangan ERD yang menjadi usulan dalam sistem informasi manajemen meliputi beberapa entitas diantaranya entitas pelanggan, penjualan, pembelian, stock data barang, supplier, dan laporan. Tiap entitas ini memiliki field yang berelasi untuk membangun suatu hubungan database yang terintegrasi/kompleks. Dalam entitas pelanggan terdapat hubungan one-to-many dengan entitas penjualan dan field yang bertanda primary key pada kedua entitas itu akan saling berelasi. Selanjutnya didalam entitas penjualan terdapat field hubungan many-to-many dari data kedua antara entitas penjualan dan entitas stock data barang pada field yang bertanda primary key. Kemuadian entitas stock data barang berelasi dengan entitas pembelian dan entitas laporan. Entitas stock data barang berelasi many-to-one dengan entitas laporan dengan field yang bertanda primary key. Sementara data kedua dari entitas stock data barang berelasi many-to-one dengan entitas pembelian yang bertanda primary keys pada field nya. Terakhir, data kedua entitas pembelian berelasi one-to-many dengan entitas supplier supplier yang bertanda primary key pada field nya.

\section{Analisis Perancangan Database}

Perancangan database ini dibuat dengan menggunakan aplikasi XAMPP yang dapat dibuka melalui aplikasi browser Mozilla Firefox dengan memasukan link localhost/phpmyadmin. Tampilan database ini bisa dibuka dalam keadaan offline. Database yang dibuat ini berdasarkan ERD yang meliputi database laporan, pelanggan, pembelian, penjualan, stock data barang dan supplier. Database ini secara otomatis akan terintegrasi dengan data yang lainnya sehingga keakuratan datanya sangat baik sekali.

\section{Analisis Perancangan Interface}




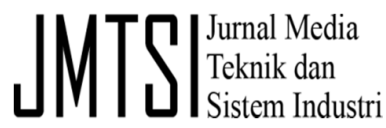

Tampilan muka ini berupa tampilan luar yang secara tidak langsung merupakan tampilan input atau masukan untuk menghubungkan database yang telah dibuat pada MySQL. Perancangan interface ini dapat diakses dengan mengaktifkan terlebih dahulu menu Apache dan MySQL pada aplikasi XAMPP. Perancangan interface ini dibuat dengan aplikasi Sublime Text 3, dimana untuk menampilkan tampilannya dilakukan input bahasa pemrograman PHP melalui coding (syntaks). Dengan demikian tampilan interface ini memudahkan dalam proses peng-input-an barang dan dapat menampilkan informasi-informasi baik pembelian atau penjualan barang.

\section{Analisis Penerapan Sistem Informasi}

Berdasarkan sistem informasi yang telah berjalan di perusahaan, diketahui bahwa sistem informasinya masih kurang dan masih menggunakan cara manual dalam peng-input-an dan melaporkan data penjualan dan pembelian. Sehingga ini dapat memungkinkan terjadinya resiko kekeliruan data. Serta kurangnya koordinasi antar bagian yang dapat menyebabkan terjadinya mis komunikasi.

Sedangkan sistem informasi persediaan yang usulkan menerapkan sistem informasi yang terkomputerisasi. Jadi dengan sistem informasi persediaan ini semua antar bagian akan terintegrasi satu sama lain. Dan di dukung dengan adanya database sebagai penyimpanan data-data perusahaan. Sistem informasi yang diusulkan ini mempermudah dalam pengerjaan, karena dalam pengerjaannya user tinggal meng-input data pada komputer. Selain itu pun, dengan sistem informasi ini dapat mengefisiensikan proses pengerjaan. Proses yang tadinya membutuhkan waktu selama 1 hari, bahkan bisa sampai 2 hari apabila stock banyak. Dengan sistem informasi persediaan, kini waktu proses pelaporan untuk mengetahui barang menjadi singkat diperkirakan hanya memerlukan waktu kurang lebih 30 menit sampai dengan 2 jam apabila stock banyak. Karena data tinggal di input dan hanya mengklik form stock data barang atau mengklik form laporan untuk melihat stock terkini selanjutnya dapat dicetak apabila dibutuhkan. Selain itu kebutuhan informasi ini akan secara otomatis dapat diketahui oleh tiap bagian. Dan pemilik dapat mengontrol ketersediaan stock tanpa harus mengecek ke bagian gudang.

Dengan demikian sistem informasi persediaan ini merubah SOP menjadi lebih efisien, serta memudahkan pemilik dan bagianbagian divisi lainnya untuk mendapatkan informasi yang akurat.

\section{KESIMPULAN}

Berdasarkan hasil penelitian yang telah dilakukan, mengenai Sistem Informasi Manajemen Persediaan menggunakan Period Order Quantity pada perusahaan PD. Teguh Kaos Polos, maka dapat disimpulkan sebagai berikut:

1. Dengan menggunakan metode Period Order Quantity dapat menetukan jumlah pemesanan yang optimal sebesar 1803 unit/pcs, frekuensi pemesanan 11 kali dengan jarak antar pemesanan 29 hari. Juga dapat menurunkan penumpukan jumlah stock sekitar 7626 unit/pcs serta menurunkan biaya pesan dan simpan pada perusahaan sekitar Rp.36.171.103,. Sehingga membantu perusahaan dalam menentukan pemesanan serta menekan biaya pesan dan simpan yang dikeluarkan oleh perusahaan.

2. PD.Teguh Kaos Polos secara fungsional membutuhkan sistem informasi yang terkomputerisasi dan terintegrasi untuk mempermudah dalam mengolah data, baik data penjualan, data pembelian ataupun laporan barang untuk membantu mengetahui persediaan stock yang tersedia di gudang. Secara non-fungsional perusahaan membutuhkan sebuah perangkat komputer CPU dengan sistem operasi minimal Windows XP, didukung dengan Software XAMPP untuk menjalankan database dan sebuah printer untuk mencetak dokumen-dokumen yang telah diolah.

3. Dengan Sistem Informasi Manajemen Persediaan menggunakan Period Order Quantity dapat menginformasikan jumlah persediaan dan merubah SOP menjadi lebih efisien dengan perkiraan waktu yang singkat sebesar 30 menit sampai 2 jam-an serta membantu pemilik dalam mengontrol stock barang yang tersedia dengan cara melihat form stock data barang atau melihat form laporan yang ditampilkan pada database yang telah dibuat.

\section{REFERENSI}

[1] Rangkuti, Manajemen Persediaan Aplikasi di Bidang Bisnis. Penerbit Rajagrafindo: Jakarta, 2007.

[2] Ristono, A. Manajemen Persediaan edisi 1. Penerbit Graha Ilmu: Yogyakarta, 2009.

[3] Assauri, S., Manajemen Produksi dan Operasi. Penerbit Rajawali Press: Jakarta, 2004.

[4] Mulyanto, A., Sistem Informasi Konsep dan Aplikasi. Penerbit Pustaka Pelajar: Yogyakarta, 2009.

[5] Putro, B.E., "Analisa Control Self Assessment Audit Pada Klausul A.5 Security Policy Hingga Klausul A.9 Physical And Environmental Security Telkom Flexi Kebon Sirih Jakarta Pusat Menggunakan ISO/IEC 27001", Media Jurnal Informatika, vol. 8, no. 1, pp. 1824, 2016. 
[6] Marzuki, Metodologi Riset panduan penelitian bidang bisnis dan sosial. Penerbit EKONISIA: Yogyakarta: 2005.

[7] Creswell, J.W., Reseach Design Pendekatan Kualitatif, Kuantitatif, dan Mixed. Penerbit Pustaka Pelajar: Yogyakarta, 2010.

[8] Bahagia, S.N., Sistem Inventori, Penerbit ITB: Bandung, 2006.

[9] Ladjamudin, Analisis dan Desain Sistem Informasi. Penerbit Graha Ilmu: Yogyakarta, 2005.

[10] Sutabri, T. Analisis Sistem Informasi. Penerbit ANDI: Yogyakarta, 2012.

[11] Ichwan, M. Pemrograman Basis Data Delphi 7 dan MYSQL. Penerbit Informatika: Bandung, 2011.

[12] Yamit, Z. Manajemen persediaan. Penerbit EKONISIA: Yogyakarta, 2008. 